\title{
Kirkbyites Johnson, a valid ostracod genus from the Upper Palaeozoic
}

\author{
GERHARD BECKER \\ Geological Palaeontological Institute, Johann Wolfgang Goethe University, \\ Senckenberg-Anlage 32-34, 6000 Frankfurt am Main, Federal Republic of Germany.
}

\begin{abstract}
Kirkbyites upsoni Johnson, 1936 from the Upper Pennsylvanian of North America, type species of the poorly understood genus Kirkbyites, corresponds significantly with the well-known species Kullmannissites? solus Becker, 1981 from the Upper Devonian of SW Europe. From common, important diagnostic characters, the latter is considered to be a species of Kirkbyites Johnson, 1936 which is a valid genus of the Family Amphissitidae Knight, 1928 (Ostracoda, Palaeocopida, Kirkbyacea).
\end{abstract}

\section{INTRODUCTION}

In 1936, W.R. Johnson published detailed studies on ostracod faunas from the Missourian (Upper Pennsylvanian) of Nebraska (USA). Therein $(1936,35)$, the kirkbyid ostracod genus Kirkbyites Johnson was established. The only described species, $K$. upsoni Johnson, 1936, is the type-species (by original designation).

Referring to Johnson (1936, 36; pl.3, figs 4-6), Kirkbyites is characterized by an elongate outline with broadly rounded cardinal angles; by a median, subglobular node, small but prominent; by a second small node, subelliptical in outline and located posterodorsally; and by two carinae along the ventral margin which converge at the cardinal angles. A kirkbyan pit was reported, and the carapace surface described as reticulate. These characters are clearly indicative of an ostracod belonging to the Family Amphissitidae Knight, 1928.

Johnson's material, however, is relatively badly preserved and therefore, the monospecific genus remained little known. Sohn (1961, 128, 130) put Kirkbyites Johnson, 1936 in synonymy with Kegelites Coryell \& Booth, 1933, type-species Girtyites spinosus Coryell \& Booth, 1933 [= Amphissites dattonensis Harlton, 1927] from the Pennsylvanian and Permian of $\mathrm{N}$. America.

\section{RECENT RESEARCH}

In connection with the revision of the "Treatise on Invertebrate Paleontology, Part Q, Paleozoic Ostracoda", Johnson's original material was loaned to the present author. The collection, the (supposed) holotype and 12 topotypic paratypes (UNSM 34721 . 34735; Stanton Formation, Eudora Shale 1; Dyson Hollow, west of La Platte, Nebraska) consists entirely of single, more or less weathered valves, yellowish in colour and belonging to different ontogenetic stages.

Having inspected the original material, it became evident to the present author that the North American species closely resembles in carapace shape and ornamentation an amphissitid species from the Famennian (Upper Devonian) of the Cantabrian Mountains (N. Spain), namely Kullmannissites? solus Becker, 1981. This species shows, on the comparatively weak posterodorsal node, a prominent spine which is considered to be a "biotope indicative feature" (Becker \& Bless, 1990); the outer carina curves - as in Kirkbyites upsoni - above the dorsum at the anterior cardinal angle (see F'ig.1); and the carapace width is narrow (see Becker, 1981, 32, 33; Pl.3, figs 8-15). It is, therefore, considered to be a species of Kirkbyites, Johnson rather than of Kullmannissites. This European taxon (see also Pl.1, figs 6-9) does not show the anterodorsal spine of Kullmannissites Becker, 1981 (Pl.1, figs 5a, 5b). Therein, it resembles Kegelites Coryell \& Booth, 1933 from which, however, it is clearly distinguished by the anterodorsally located carinal flange and by the narrow carapace width. The amphissitid genus Sinessites Becker, 1981 (Pl.1, figs 4a, 4b) has the carina curving at the dorsum at both cardinal angles, but has no lateral nodes or spines.

The characteristic features described in Kirkbyites solus (Becker), and not mentioned by Johnson (1936), can be observed in Kirkbyites upsoni Johnson (P1.1, figs 1-3). In several specimens, the outer carina clearly curves above the dorsum at the anterior cardinal angle (see also Fig. 1B). K. upsoni is (mainly) distinguished from $K$. solus by the more prominent posterodorsal node, on which was apparently situated a rather delicate spine, and by a transverse ridge on the subcentral node.

\section{PALAEOECOLOGY}

Kirkbyites solus (Becker, 1981) comes from nodule-bearing marls. It belongs to the so-called "Thuringian" eco-assemblage, indicative of low-energy environments (Becker, 1982, 164). In Kirkbyites, the dorsal spines are considered to be important "biotope indicative features" (Becker \& Bless, 1990).

Kirkbyites upsoni Johnson, 1936 is reported from grey shales (Johnson, 1936, 4), but, unfortunately, associated faunas are not given. Referring to Keroher et al. (1967, 3708), the dark shales of the Stanton Formation contain some nodular limestones, possibly indicating similar environments. The occurrence of species, some of which have "biotope indicative" spines, belonging to Kirkbva Ulrich \& Bassler, Amphissites Girty, Ulrichia Jones, Roundyella Knight and Silenites Coryell \& Booth at the Eudora Shale localities may confirm this assumption.

\section{ACKNOWLEDGEMENTS}

The original materials were loaned by kind permission of 
Prof. R.K. Pabian, University of Nebraska, Nebraska State Museum, Lincoln, USA [UNSM], and Dr Heinz Malz, Forschungs-Institut Senckenberg, Frankfurt am Main, FRG [SMF]. I am also greatly indebted to Dr A.R. Lord, Micropalaeontology Unit, Department of Geology, University College London, England, UK, for reading and refining the manuscript.

\section{Manuscript received August 1990}

Revised manuscript accepted October 1990

\section{REFERENCES}

Becker, G. 1981. Ostracoden aus cephalopoden-fürendem Oberdevon im Kantabrischen Gebirge (N-Spanien). 1. Hollinacea, Primitiopsacea, Kirkbyacea, Healdiacea und Bairdiocypridacea. Palaeontographica, Stuttgart, A 173, 1-63, 7 text-figs, 2 tabs, pls $1-11$.

Becker, G. 1982. Ostracoden aus cephalopoden-führendem Oberdevon im Kantabrischen Gebirge (N-Spanien). 2. Bairdiacea, Cytheracea, Entomozoacea. Paleontographica, Stuttgart, A 178, 109-182, 6 text figs, 2 tabs, pls $1-10$

Becker, G. \& Bless, M.J.M. 1990. Biotope indicative features in Palaeozoic ostracods: a global phenomenon. In: Whatley, R. and Maybury, C. (Eds), Ostracoda and Global Events, Chapman \& Hall, London, 421-436.

Johnson, W.R. 1936. The Ostracoda of the Missouri series in Nebraska. Pap Nebraska Geol. Surv, Lincoln/Nebr., 11, 1-52, pls 1-5

Keroher, G.C. (ed.) 1967. Lexique stratigraphique international, 7, 1, Amérique du Nord, Etats-Unis, 1-4341. Paris

Sohn, I.G. 1961. Aechminella, Amphissites, Kirkbyella and related genera. U.S. Geol. Surv. Prof. Pap., Washington/D.C., 330 B, 107-160, text figs 16-31, pls 7-12.

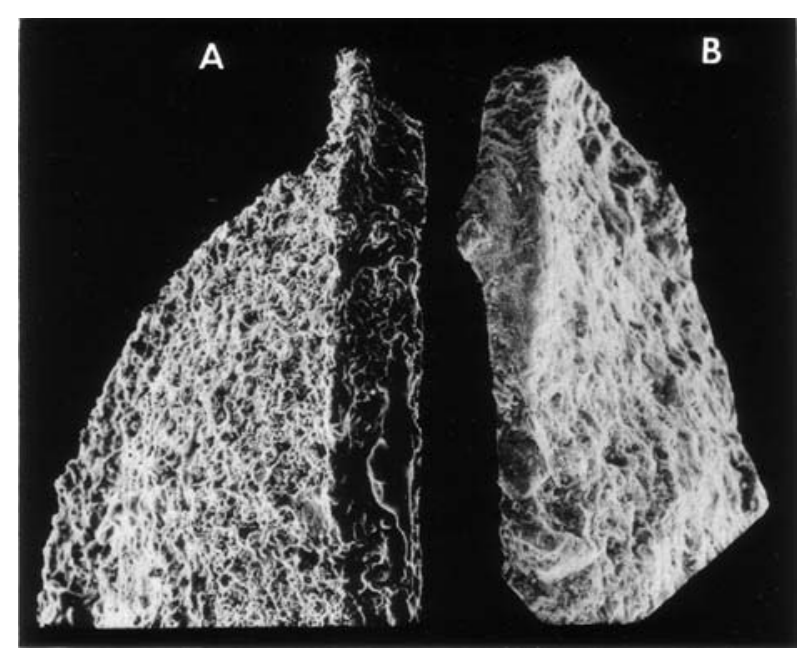

Fig. 1 Characteristic feature in Kirkbyites Johnson, 1936 - the anterodorsally located carinal flange; fig. A, $K$. solus (Becker, 1981), holotype SMF Xe 11217, anterior part of left valve, dorsal view (x130); fig. B, K. upsoni Johnson, 1936, paratype UNSM 34727, anterior part of right valve, dorsal view (x110).

Fig. 1 Kirbyites upsoni Johnson, 1936, adult left valve, paratype UNSM 34732, external view (length $=1070 \mu \mathrm{m}$ ).

Fig. 2 Kirkbyites upsoni Johnson, 1936, juvenile right valve, paratype UNSM 34727; fig.2a, external view; fig.2b, ventral view; fig.2c, anterior view (length $=980 u \mathrm{~m}$ ).

Fig. 3 Kirkbyites upsoni Johnson, 1936, juvenile right valve, paratype UNSM 34722, dorsal view (length $=840 \mu \mathrm{m}$ ).

Fig. 4 Sinessites hispanicus Becker, 1981, adult right valve, holotype SMF Xe 11191; fig.4a, external view; fig.4b, dorsal view (length = 1070um).

Fig. 5 Kullmannissites kullmanni Becker, 1981, adult left valve, holotype SMSF Xe 11204; fig.5a, external view; fig.5b dorsal view (length $=1270 \mu m$ ).

Fig. 6 Kirbyites solus (Becker, 1981), juvenile right valve, paratype SMF Xe 11221; fig.6a, external view; fig.6b, ventral oblique view (length $=760 \mu \mathrm{m}$ ).

Fig. 7 Kirkbyites solus (Becker, 1981), juvenile right valve, paratype SMF Xe 11219, external view (length $=1170 \mu \mathrm{m}$ ).

Fig. 8 Kirkbyites solus (Becker, 1981), adult left valve, holotype SMF Xe 11217; fig.8a, external view; fig.8b, dorsal view; fig.8c, anterior view (length $1480 \mu \mathrm{m})$.

Fig. 9 Kirkbvites solus (Becker, 1981), adult right valve, paratype SMF Xe 11220, ventral view (length $=1430 \mu \mathrm{m})$. 


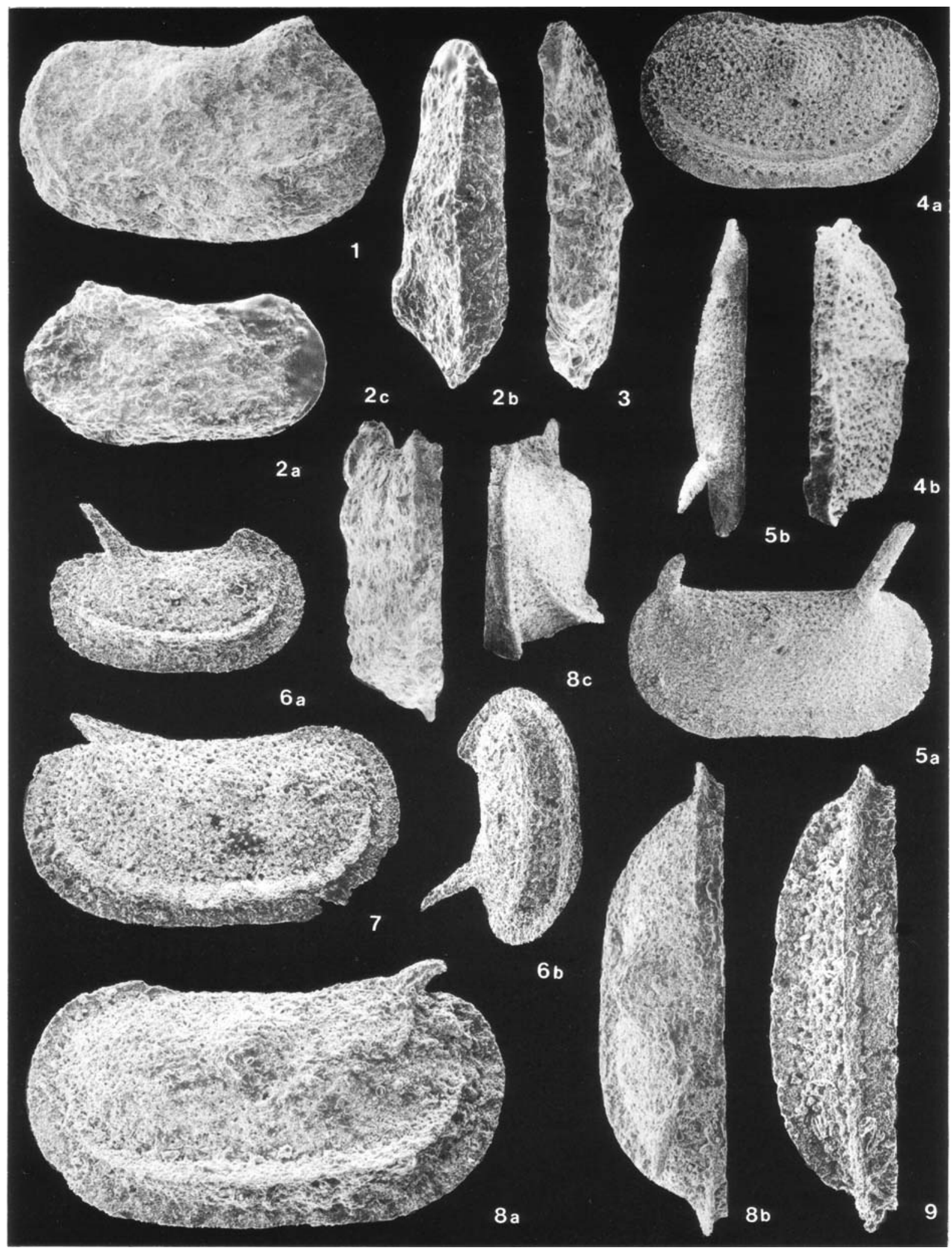

